\title{
Analisis Spasial Arus Retas sebagai Upaya Pengurangan Risiko Bencana di Desa Parangtritis Yogyakarta
}

\author{
Bachtiar W. Mutaqin, Mulyadi Alwi, Natasya Michelle Adalya
}

Masuk: 05102021 / Diterima: 03112021 / Dipublikasi: 01122021

\begin{abstract}
Parangtritis in Yogyakarta is included in the priority of regional tourism development based on Yogyakarta's Regulation Number 1 of 2019 since it was very famous with the number of tourists reaching 2.8 million people in 2019. On the other hand, data from the regional disaster management agency in Bantul and Parangtritis's Search and Rescue in 2009-2015 shows a high number of rip currents' victims. Therefore, there needs to be an effort to identify and convey information to tourists related to rip currents on Parangtritis beach. Identification of the rip currents' presence was made during two different seasons, namely the east and west monsoons, by visual interpretation through satellite imagery by paying attention to the presence of beach cusps and where waves are not breaking. This is because the hydrooceanographic parameters may change in response to the seasons, which also impact the morphology of the coast. This study analyzes morphology, morphometry, and morpho-arrangement to identify the presence, type, circulation, and danger of rip currents at Parangtritis. Eleven locations of rip currents during the east monsoon were found more evenly distributed along the shore in Parangtritis Village than 12 rip currents' locations during the west monsoon. Rip currents in Parangtritis are very dynamic, so it is necessary to disseminate related information on the rip currents' hazards to tourists and tourism actors as one of the mitigation and disaster risk reduction efforts in Parangtritis Village.
\end{abstract}

Key words: Hazard; Beach Tourism; Mitigation; Rip Currents; Parangtritis

Abstrak Pantai di Desa Parangtritis, Yogyakarta termasuk dalam prioritas pengembangan pariwisata daerah berdasarkan Peraturan Daerah DIY Nomor 1 tahun 2019 dengan jumlah wisatawan yang mencapai 2,8 juta orang pada tahun 2019. Di sisi lain, data dari BPBD Kabupaten Bantul dan SAR Satlinmas Wilayah III Parangtritis tahun 2009-2015 menunjukkan tingginya jumlah korban arus retas. Oleh karena itu, perlu adanya suatu upaya identifikasi dan penyampaian informasi kepada wisatawan terkait dengan keberadaan arus retas di pantai-pantai yang ada di Desa Parangtritis. Identifikasi keberadaan arus retas dilakukan pada dua waktu yang berbeda, yaitu pada musim timur dan musim barat, dengan melakukan interpretasi visual melalui citra satelit dan memperhatikan keberadaan gisik tanduk maupun zona pecah gelombang yang terpotong. Hal tersebut dikarenakan morfologi pantai dapat berubah sebagai respon dari musim yang berdampak pada aktivitas gelombang, arus, dan pasang surut yang berbeda pula. Penelitian ini bertujuan untuk menganalisis morfologi, morfometri, dan morfoaransemen untuk menemukenali keberadaan, tipe, sirkulasi, dan bahaya arus retas di Pantai Parangtritis. Kemunculan 11 lokasi arus retas pada saat bulan Agustus/musim timur lebih tersebar secara merata di sepanjang pantai di Desa Parangtritis dibandingkan dengan 12 lokasi saat bulan April/musim barat. Arus retas di Desa Parangtritis sangat dinamis sehingga perlu adanya upaya diseminasi informasi bahaya arus retas pada wisatawan dan pelaku wisata sebagai salah satu tindakan mitigasi dan pengurangan risiko bencana di Desa Parangtritis.

Kata kunci: Bahaya; Wisata Pantai; Mitigasi; Arus Retas; Parangtritis

This is an open access article under the CC BY-SA license.

Copyright (C) 2021 by Author. Published by Universitas Pendidikan Ganesha.

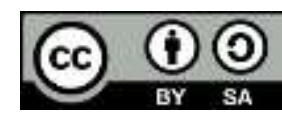




\section{Pendahuluan}

Indonesia sebagai negara kepulauan mempunyai wilayah kepesisiran yang sangat luas dengan 16.671 pulau yang sudah didaftarkan ke Perserikatan Bangsa-Bangsa (PBB) (Kemendagri, 2020) dan panjang garis pantai mencapai $108.000 \mathrm{~km}$ (KKP, 2019). Wilayah kepesisiran di Indonesia merupakan wilayah yang sangat strategis dalam menunjang perekonomian nasional dan pelaksanaan pembangunan melalui berbagai aktivitas pariwisata, jasa, budaya, maupun industri (Helmi et al., 2018; Marfai et al., 2020; Mutaqin, 2017; Mutaqin, Marfai, Helmi, Nurhadi, et al., 2020; Mutaqin, Marfai, Helmi, Rindarjono, et al., 2020). Namun demikian, di sisi lain wilayah kepesisiran merupakan wilayah yang mempunyai potensi bahaya, seperti arus retas, erosi, sedimentasi, deflasi, tsunami, dan bencana kepesisiran lainnya (Helmi et al., 2020; Mutaqin, 2017; Mutaqin, Yuendini, Aditya, Rachmi, et al., 2020).

Salah satu wilayah yang mempunyai beragam Daerah Tujuan Wisata (DTW) di wilayah kepesisiran adalah Kabupaten Bantul di Provinsi Daerah Istimewa Yogyakarta (DIY). Kabupaten Bantul mempunyai garis pantai sepanjang $16,85 \mathrm{~km}$ dan terkenal dengan objek wisata pantai (Mutaqin, 2017; Yulianto, 2018), seperti Pantai Parangtritis, Pantai Parangkusumo, dan Pantai Depok (Gambar 1). Ketiga pantai tersebut termasuk dalam prioritas pengembangan pariwisata daerah berdasarkan Peraturan Daerah DIY Nomor 1 tahun 2019 tentang Rencana Induk Pembangunan Kepariwisataan Daerah Provinsi Daerah Istimewa Yogyakarta Tahun 2012-2025 .

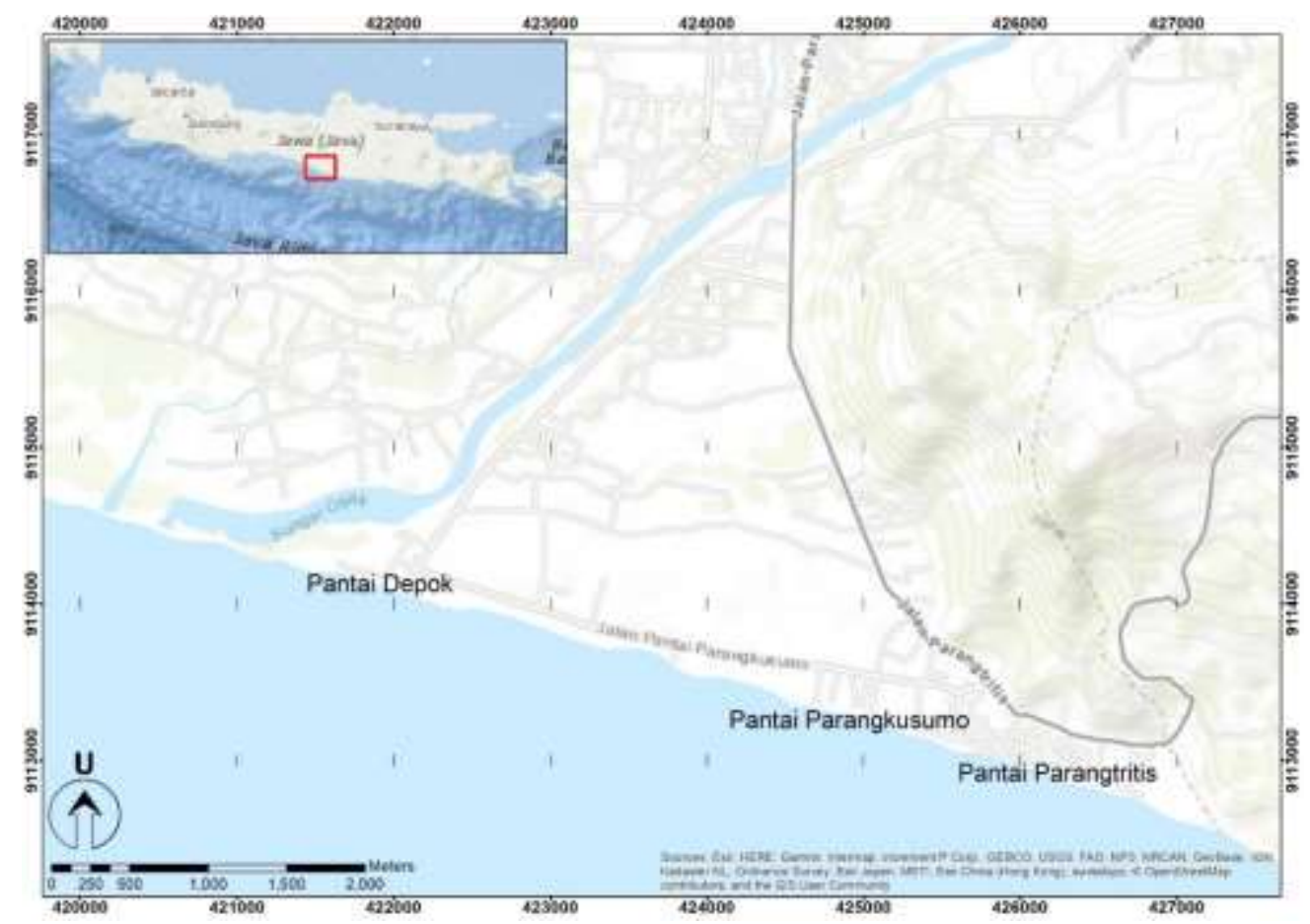

Gambar 1. Tiga objek wisata pantai yang terkenal di Kabupaten Bantul, yaitu Pantai Parangtritis, Pantai Parangkusumo, dan Pantai Depok 
Jumlah wisatawan yang mengunjungi kawasan Parangtritis pada tahun 2019 mencapai 2,8 juta orang (BPS Kabupaten Bantul, 2020). Situasi pandemi Covid-19 sejak awal tahun 2020 ternyata sama sekali tidak menyurutkan minat wisatawan untuk mengunjungi ketiga pantai tersebut. Meskipun terjadi penurunan jumlah pengunjung sebanyak 1,1 juta orang, Bantul masih bisa memenuhi capaian target kunjungan wisata tahun 2020 dengan capain PAD lebih dari Rp 16 miliar, melebihi dari target awal yaitu 14 miliar (Republika, 2020). Dilihat dari tren pencarian di Google dalam kurun waktu 5 tahun terakhir, penggunaan kata kunci Parangtritis termasuk dalam kategori tinggi (Gambar 2).

Namun demikian, tingginya jumlah wisatawan apabila tidak dikelola dengan baik akan dapat meningkatkan risiko kecelakaan laut sebagai akibat dari adanya arus retas atau rip current di tiga pantai tersebut (Retnowati, 2013; Sherker et al., 2010; Susmayadi et al., 2010).

Arus retas atau rip current merupakan arus di dekat pantai yang sangat berbahaya, terkonsentrasi melewati jalur sempit yang mengalir kuat ke arah laut pada zona pecah gelombang (surf zone) dan melintasi gelombang pecah sampai ke lepas pantai. Arus retas bergerak ke arah laut dengan kecepatan mencapai 2 meter/detik. Keberadaan arus retas di perairan Bantul dapat dicirikan pada pantai berpasir yang mempunyai bentuk seperti tanduk dan di perairan dekat pantainya terbentuk gosong/endapan sedimen yang berbentuk seperti bulan sabit.

\begin{tabular}{|c|c|c|c|c|c|c|c|c|c|c|}
\hline Wurldwide - & & 5 vears & All categories & $\cdot$ & & b Search * & & & & \\
\hline interest over time & (9) & e & Gumuk pasit Para... & i & e & Pantai Parangtritis & ㅇ & Pantai Depok & \pm & $\Leftrightarrow<$ \\
\hline
\end{tabular}

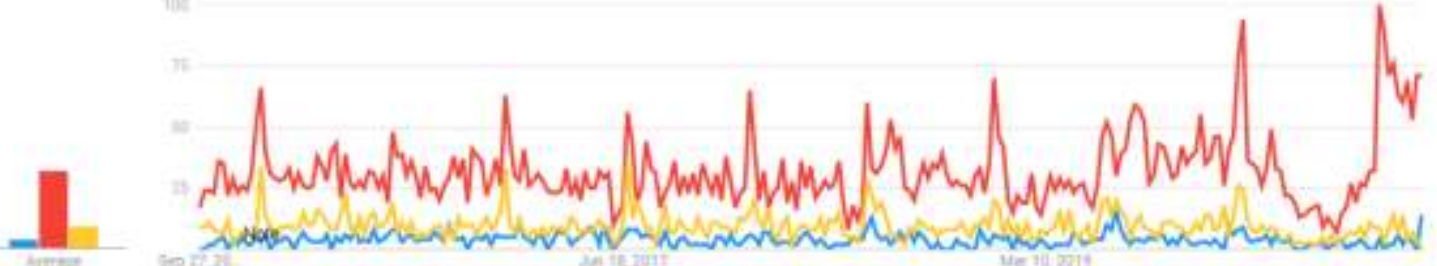

Gambar 2. Tren pencarian di Google dengan kata kunci Pantai Parangtritis 2015-2020.

Data dari Badan

Penanggulangan Bencana Daerah Kabupaten Bantul dan SAR Satlinmas Wilayah III Parangtritis tahun 2009-

Bachtiar W. Mutaqin, Mulyadi Alwi, Natasya M. Adalya Universitas Gadjah Mada, Indonesia

mutaqin@ugm.ac.id
2015 menunjukkan bahwa setidaknya ada 508 wisatawan yang terbawa arus retas (Tabel 1) (Indrapertiwi, 2016). Jumlah tersebut termasuk tinggi apabila dibandingkan dengan hasil penelitian dari National Weather Service's East Central Florida Rip Current Program di Pantai Florida, Amerika Serikat yang 
menyebutkan bahwa dalam kurun waktu 1989-1999 terjadi 150 kasus (15 kasus/tahun) akibat terseret arus retas (Kusmanto \& Setyawan, 2011). Hal tersebut dapat memberikan gambaran bahwa wisata pantai yang sangat digemari oleh para wisatawan mempunyai bahaya yang harus diwaspadai yang berupa keberadaan arus retas.

Tabel 1. Data jumlah korban kecelakaan laut di kawasan Parangtritis tahun 2009-2015 (Indrapertiwi, 2016).

\begin{tabular}{cccc}
\hline Tahun & Selamat & Meninggal & Hilang \\
\hline 2009 & 61 & 6 & 2 \\
2010 & 70 & 9 & 3 \\
2011 & 58 & 4 & - \\
2012 & 107 & 1 & - \\
2013 & 37 & 1 & 1 \\
2014 & 59 & 5 & - \\
2015 & 81 & 3 & - \\
\hline
\end{tabular}

Kasus korban arus retas di Bantul dapat disebabkan karena dua hal utama. Pertama, ketidaktahuan wisatawan akan kondisi pantai yang mereka kunjungi, khususnya terkait keberadaan arus retas yang ada di kawasan Parangtritis. Kedua, masih minimnya peralatan yang dimiliki oleh SAR Satlinmas. Hasil diskusi dengan koordinator SAR Satlinmas wilayah III Parangtritis, $M$. Arief Nugraha, menunjukkan bahwa saat ini tim SAR masih kekurangan alat pendukung berupa pengeras suara dan ramburambu bahaya lokasi arus retas.

Untuk mengantisipasi timbulnya korban yang lebih banyak lagi, perlu adanya suatu upaya identifikasi dan penyampaian informasi kepada wisatawan terkait dengan keberadaan arus retas di pantai-pantai yang berlokasi di Kabupaten Bantul. Identifikasi keberadaan arus retas tersebut dilakukan pada dua waktu yang berbeda, yaitu pada Musim Timur dan Musim Barat. Hal tersebut dikarenakan morfologi pantai dapat berubah sebagai respon dari musim yang berdampak pula pada aktivitas gelombang, arus, dan pasang surut. Oleh karena itu, penelitian ini bertujuan untuk menganalisis morfologi, morfometri, dan morfoaransemen untuk menemukenali keberadaan, tipe, sirkulasi, dan bahaya arus retas untuk mendukung keselamatan aktivitas pariwisata pantai di Desa Parangtritis.

\section{Metode}

Penelitian ini dilaksanakan di wilayah kepesisiran Kabupaten Bantul, yaitu di Desa Parangtritis, Kecamatan Kretek pada bulan April yang mewakili musim barat dan bulan Agustus (musim timur). Pemilihan lokasi tersebut didasarkan pada keberadaan pantai yang menjadi prioritas pengembangan wisata pantai berdasarkan Peraturan Daerah DIY Nomor 1 tahun 2019, yaitu Pantai Parangtritis, Pantai Parangkusumo, dan Pantai Depok.

Penelitian ini dilakukan dengan menelusuri lokasi kemunculan arus retas saat musim timur dan musim barat dengan menggunakan citra satelit Sentinel-2 dengan resolusi spasial 10 meter dan dilakukan berdasarkan aspek morfologi, morfometri, dan morfoaransemen. Penelitian ini menggunakan pendekatan gabungan antara metode kualitatif dan kuantitatif (Mixing Qualitative and Quantitative Approach). Alasan pemilihan metode tersebut adalah terkait dengan keterbatasan angka atau nilai dalam 
metode kuantitatif yang hanya mampu mengungkapkan sebagian kondisi di lapangan, tidak mampu menjelaskan kondisi lapangan secara keseluruhan (kompleks). Dengan menggunakan metode tersebut, diharapkan metode kuantitatif dapat melengkapi metode kualitatif. Metode kualitatif yang diterapkan mampu menjawab beberapa pertanyaan yang menyangkut prosesproses yang terjadi di lokasi penelitian dan kemudian bermuara pada suatu kondisi perbedaan tingkat perilaku pada objek penelitian.

Metode kualitatif pada penelitian ini dilakukan untuk mengidentifikasi lokasi keberadaan arus retas dan proses-proses morfodinamika yang mampu membangun sirkulasi arus retas. Sedangkan metode kuantitatif dalam penelitian ini digunakan untuk menganalisis faktor-faktor pembangkit arus retas pada musim timur dan musim barat selama satu tahun, seperti angin dan gelombang (Hadi, 2002). Metode pengumpulan data yang dilakukan dalam penelitian ini adalah dengan teknik observasi yang dilakukan pada objek kajian yang bukan manusia melalui interpretasi citra satelit. Permukaan bumi yang memiliki kenampakan sangat kompleks dan foto udara atau citra satelit merupakan rekaman kondisi permukaan bumi seperti apa adanya yang tertangkap oleh kamera (Yunus, 2011). Oleh karena itu, kenampakan yang ada juga menampilkan gambaran permukaan bumi yang kompleks. Keberadaan arus retas dapat diidentifikasi melalui citra satelit dengan memperhatikan aspekaspek tertentu. Sedangkan informasi faktor-faktor pembangkit arus retas diperoleh melalui studi literatur, pengamatan, serta pengukuran di lapangan.

3. Hasil dan Pembahasan

\section{Identifikasi Lokasi Arus Retas Berdasarkan Citra Satelit}

Keberadaan arus retas di sepanjang pantai di Desa Parangtritis ditemukenali berdasarkan pendekatan citra penginderaan jauh melalui interpretasi visual dari citra satelit Sentinel-2 perekaman awal tahun (April) yang mewakili kondisi musim barat dan pertengahan tahun (Agustus) yang mewakili musim timur. Identifikasi lokasi arus retas melalui citra penginderaan jauh diperoleh dengan cara mengamati dan mengidentifikasi surf zone atau zona gelombang pecah. Apabila terdapat perpotongan surf zone maka dapat diidentifikasi pada lokasi tersebut merupakan lokasi arus retas.

Arus retas yang diidentifikasi dari citra satelit secara umum mempunyai morfologi yang terbagi menjadi bibit arus/pengisi (feeder), leher arus (neck), dan kepala arus (head). Bibit arus/pengisi dicirikan dengan pergerakan arus susur pantai yang masuk ke dalam pantai dengan morfologi cekung. Leher arus dicirikan dengan bentuk arus yang tegak lurus dengan garis pantai. Kepala arus dicirikan dengan arus di luar zona pecah gelombang. Kepala arus merupakan akhir dari fenomena arus retas sebagai akibat dari kecepatan yang semakin melemah. Contoh ciri-ciri kenampakan arus retas dari citra penginderaan jauh dapat dilihat pada Gambar 3. Lokasi arus retas berdasarkan interpretasi citra satelit pada bulan April dan Agustus dapat dilihat pada Gambar 4. 


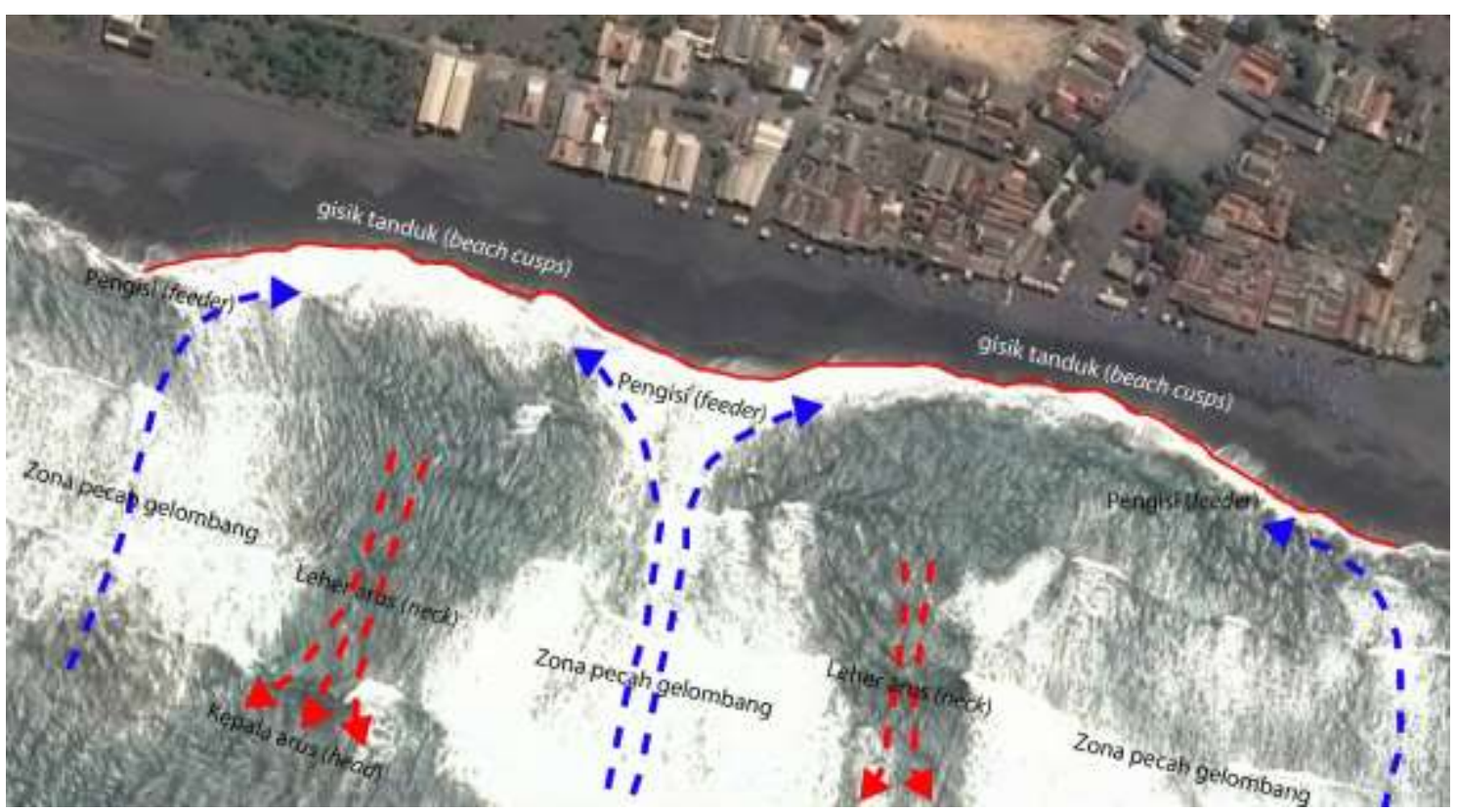

Gambar 3. Salah satu ciri-ciri kenampakan arus retas yang dapat diidentifikasi melalui citra penginderaan jauh Worldview-2 di Google Earth pada bulan Agustus. Arus retas dapat diidentifikasi salah satunya dari keberadaan gisik tanduk dan perpotongan zona pecah gelombang.

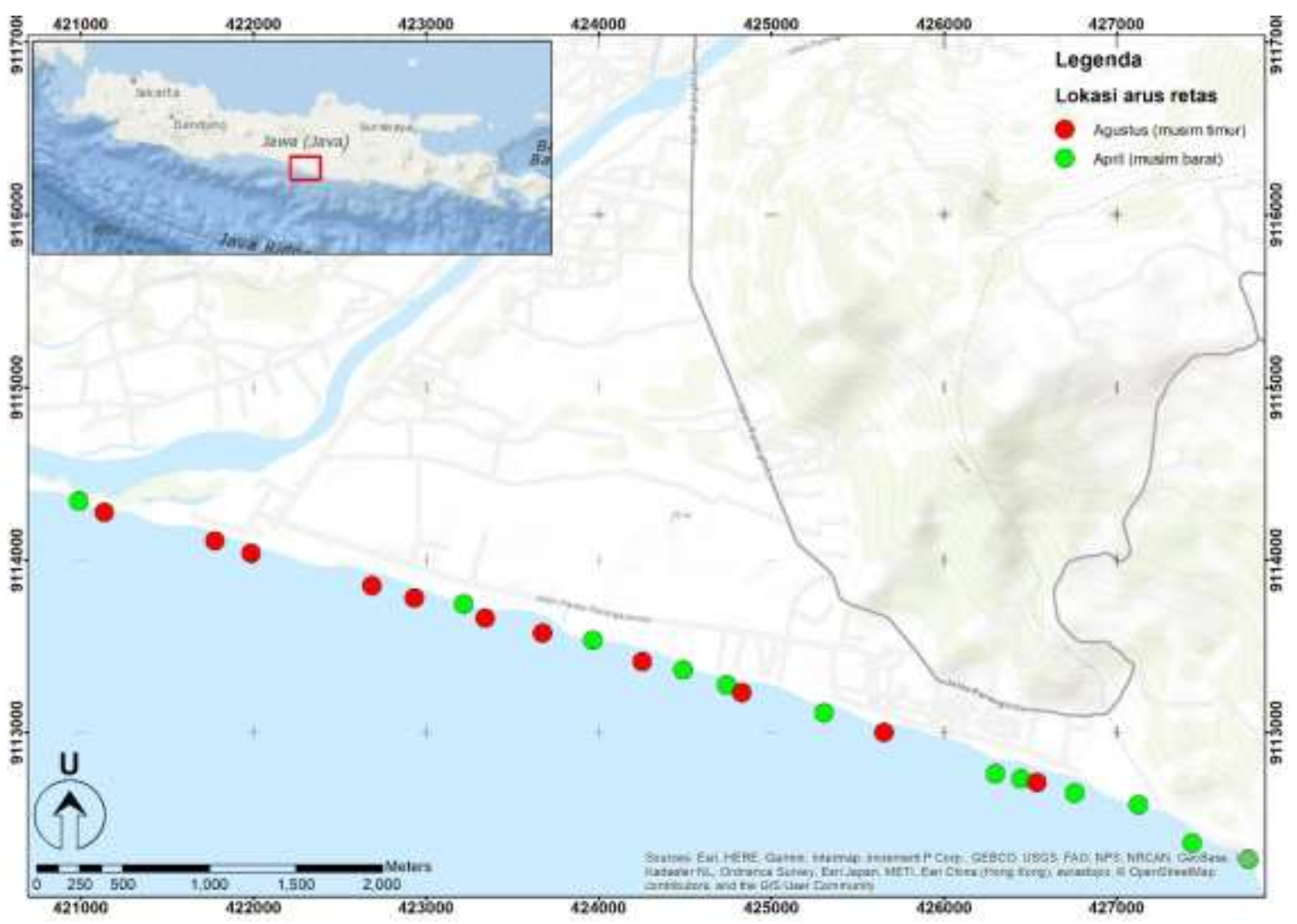

Gambar 4. Lokasi arus retas berdasarkan interpretasi citra pada musim barat (hijau) dan musim timur (merah). 
Interpretasi kedua citra tersebut menunjukkan bahwa terdapat perbedaan lokasi dan jumlah dari arus retas. Terlihat jelas bahwa jumlah kemunculan arus retas lebih tersebar secara merata di sepanjang pantai di Desa Parangtritis pada saat bulan Agustus (musim timur) dibandingkan dengan bulan April (musim barat). Arus retas yang terbentuk pada saat musim timur tersebar di 11 lokasi, sedangkan arus retas pada musim barat yang berhasil diidentifikasi ada pada 12 lokasi. Hasil tersebut diperoleh berdasarkan identifikasi visual pada citra dengan memperhatikan ciri-ciri dari kenampakan arus retas, yaitu kenampakan morfologi gisik tanduk dan perpotongan pada zona pecah gelombang (surf zone) (Bruijn, 2005; Caldwell et al., 2013; Castelle et al., 2016).

\section{Informasi Lokasi Arus Retas Untuk Sistem Peringatan Dini}

Arus retas mempunyai

kecepatan yang sangat kuat dan terjadi pada tipe morfologi gisik tanduk (beach cusp). Pertemuan arus susur pantai yang bergerak mengumpul pada pantai dengan morfologi gisik tanduk berpotensi menimbulkan arus retas yang kuat (Drozdzewski et al., 2015; Hong et al., 2021; Ostrowski et al., 2020). Arus retas merupakan salah satu fenomena yang sulit diidentifikasi tingkat bahayanya karena salah satu sifatnya yang dinamis. Dinamika wilayah kepesisiran menyebabkan perubahan garis pantai dan morfologi pantai, sehingga lokasi terjadinya arus retas bersifat dinamis (Castelle et al., 2016; Ferrari et al., 2019).
Dinamika ini perlu dikaji terkait dengan jumlah wisatawan yang berkunjung di wilayah kepesisiran Kabupaten Bantul. Pendekatan yang dapat dilakukan adalah dengan mengidentifikasi kejadian arus retas baik dari citra maupun pengamatan langsung. Wisatawan yang berkunjung untuk menikmati keindahan panorama pantai, termasuk di Desa Parangtritis Kabupaten Bantul, sangat berpotensi untuk dapat masuk dalam lokasi yang berpotensi terjadinya arus retas. Hal tersebut dikarenakan ketidaktahuan dan kurangnya informasi yang tersedia terkait dengan bahaya arus retas di pantai-pantai yang mereka kunjungi (Ballantyne et al., 2005; Brannstrom et al., 2014; Caldwell et al., 2013). Jumlah wisatawan yang menjadi korban akibat arus retas dan tercatat oleh SAR Kabupaten Bantul antara tahun 20012013 dapat dilihat pada Gambar 5.

Berdasarkan Gambar 5, dapat dianalisis bahwa jumlah pengunjung atau wisatawan yang terbawa arus retas cenderung tidak ada perubahan berarti dan rata-rata mencapai lebih dari 30 orang per tahunnya. Hal ini tentu saja dapat disebabkan karena beberapa faktor, salah satunya adalah karena terputusnya informasi antara akademisi, praktisi keselamatan pantai, dan pengunjung pantai, yang menyebabkan kesenjangan dalam pengetahuan mengenai bahaya arus retas (Brander \& MacMahan, 2011).

Selain itu, ketiadaan informasi yang disediakan oleh pengelola wisata pantai (pemerintah maupun swasta) tentang bahaya arus retas yang ada di lokasi pantai tersebut dapat berpotensi meningkatkan jumlah korban arus retas. Oleh karena itu, analisis 
deskriptif telah dilakukan terkait informasi lokasi arus retas yang telah disampaikan sebelumnya. Analisa deskriptif dilakukan terhadap data dan peta bahaya yang disebabkan karena lokasi arus retas pada musim timur maupun musim barat di wilayah kepesisiran Desa Parangtritis di Kabupaten Bantul.

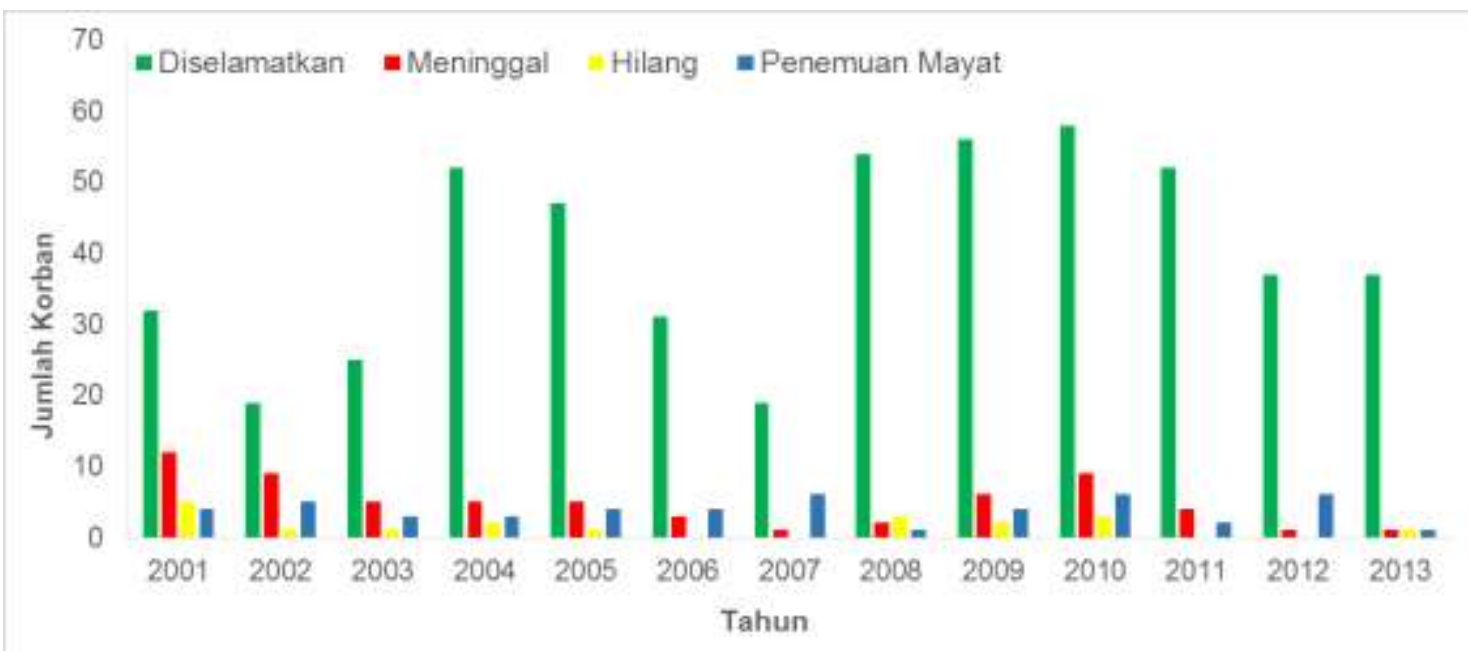

Gambar 5. Jumlah korban karena arus retas di Kabupaten Bantul tahun 2001-2013.

Informasi lokasi arus retas tersebut dapat digunakan sebagai salah satu dasar dalam sistem peringatan dini bahaya pantai (Carey \& Rogers, 2005). Dengan mengetahui informasi tersebut, diharapkan dapat meningkatkan kapasitas masyarakat lokal dan para wisatawan dalam menghadapi bahaya pantai yang berupa arus retas dan meluruskan kesalahpahaman seperti perairan yang tenang pasti aman dan arus retas hanya mungkin terjadi di wilayah dengan gelombang besar (Ballantyne et al., 2005; Brannstrom et al., 2014; Caldwell et al., 2013).

Salah satu upaya yang paling sederhana adalah dengan mengembangkan budaya masyarakat yang sadar bahaya atau sadar bencana melalui sosialisasi maupun pamfletpamflet terkait, serta memperbanyak pemasangan papan informasi maupun bendera peringatan sebagai penanda lokasi-lokasi yang diidentifikasi terdapat arus retas (Branche \& Stewart, 2001; Fenner, 2000; Hartmann, 2006; Sherker et al., 2010) (Gambar 6).

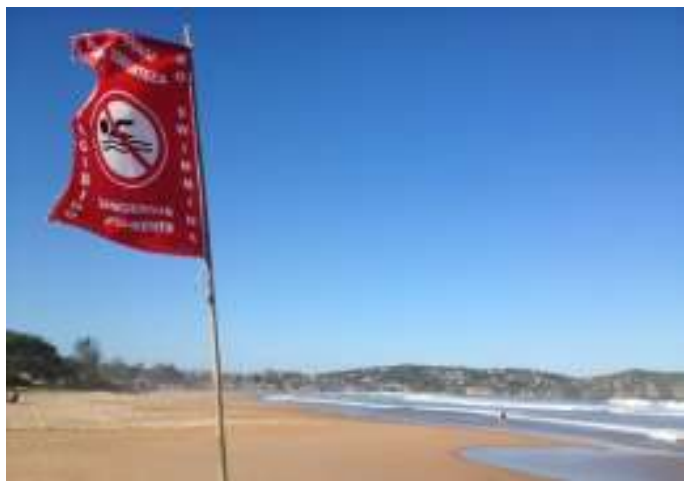

Gambar 6. Salah satu upaya sistem peringatan dini bahaya arus retas yang ada di Rio de Janeiro, Brazil (Courtesy:

B.W. Mutaqin). 


\section{Penutup}

Berdasarkan hasil penelitian dapat disimpulkan bahwa jumlah kemunculan arus retas lebih tersebar secara merata di sepanjang pantai di Desa Parangtritis pada saat bulan Agustus/musim timur dibandingkan dengan bulan April/musim barat. Jumlah arus retas yang dapat diidentifikasi pun berbeda, yaitu 11 lokasi saat musim timur dan 12 lokasi saat musim barat. Melihat sebaran arus retas yang dinamis dan jumlah pengunjung atau wisatawan yang cukup banyak di Desa Parangtritis, maka perlu adanya upaya diseminasi informasi arus retas pada wisatawan dan pelaku wisata di Desa Parangtritis sebagai salah satu tindakan mitigasi dan pengurangan risiko terkait dengan bahaya arus retas.

\section{Ucapan Terima Kasih}

Penelitian ini merupakan luaran hibah mandiri Fakultas Geografi Universitas Gadjah Mada. Penulis menyampaikan terima kasih kepada reviewer atas komentar dan masukkan yang membangun untuk perbaikan artikel ini.

\section{Daftar Pustaka}

Ballantyne, R., Carr, N., \& Hughes, K. (2005). Between the flags: an assessment of domestic and international university students' knowledge of beach safety in Australia. Tourism Management, 26(4), 617-622. https://doi.org/10.1016/J.TOURMA N.2004.02.016

BPS Kabupaten Bantul. (2020). Kabupaten Bantul dalam Angka 2020.

Branche, C. M., \& Stewart, S. (2001).
LifeguardReport - A Report of the Working Group.

Brander, R., \& MacMahan, J. H. (2011). Future Challenges for Rip Current Research and Outreach. In S. Leatherman \& J. Fletemeyer (Eds.), Rip Currents: Beach Safety, Physical Oceanography, and Wave Modeling (p. 310). CRC Press.

Brannstrom, C., Trimble, S., Santos, A., Brown, H. L., \& Houser, C. (2014). Perception of the rip current hazard on Galveston Island and North Padre Island, Texas, USA. Natural Hazards, 72(2), 11231138. https://doi.org/10.1007/s11069014-1061-3

Bruijn, J. de. (2005). Rip Current Morphologically Important and a Hazard to Swimmers. Utrecht University, The Netherlands.

Caldwell, N., Houser, C., \& MeyerArendt, K. (2013). Ability of beach users to identify rip currents at Pensacola Beach, Florida. Natural Hazards, 68(2), 1041-1056. https://doi.org/10.1007/s11069013-0673-3

Carey, W., \& Rogers, S. (2005). Rip Current: Coordinating Coastal Research, outreach, and forecast methodologies to improve public safety. Solutions to Coastal Disasters, 285-296.

Castelle, B., Scott, T., Brander, R. W., \& McCarroll, R. J. (2016). Rip current types, circulation and hazard. Earth-Science Reviews, 163, $1-21$. https://doi.org/10.1016/J.EARSCIR EV.2016.09.008

Drozdzewski, D., Roberts, A., Dominey- 
Howes, D., \& Brander, R. (2015). The Experiences of Weak and Non-Swimmers Caught in Rip Currents at Australian Beaches. Australian Geographer, 46(1), 1532.

https://doi.org/10.1080/00049182.2 014.953735

Fenner, P. (2000). Drowning awareness. Prevention and treatment. Australian Family Physician, 29(11), 1045-1049.

Ferrari, M., Carpi, L., Pepe, G., Mucerino, L., Schiaffino, C. F., Brignone, M., \& Cevasco, A. (2019). A geomorphological and hydrodynamic approach for beach safety and sea bathing risk estimation. Science of The Total Environment, 671, 1214-1226. https://doi.org/10.1016/J.SCITOTE NV.2019.03.378

Hadi, S. (2002). Arus Laut. Institut Teknologi Bandung.

Hartmann, D. (2006). Drowning and Beach-Safety Management (BSM) along the Mediterranean beaches of Israel - A long-term perspective. Journal of Coastal Research, 22(6), 1505-1514. https://doi.org/10.2112/05-0497.1

Helmi, M., Pholandani, Y. H., Setiyono, H., Wirasatriya, A., Atmodjo, W., Widyaratih, R., \& Suryoputro, A. A. D. (2020). Intergrated approach of tsunami vulnerability assessment at coastal area of kalianda sub district, south lampung district, lampung Province, Indonesia. International Journal of Scientific and Technology Research, 9(3), 1803-1808.

Helmi, M., Purwanto, Atmodjo, W., Subardjo, P., \& Aysira, A. (2018).
Benthic diversity mapping and analysis base on remote sensing and seascape ecology approach at Parang Islands, Karimunjawa National Park, Indonesia. International Journal of Civil Engineering and Technology, 9(11), 227-235.

Hong, X., Zhang, Y., Wang, B., Zhou, S., Yu, S., \& Zhang, J. (2021). Numerical study of rip currents interlaced with multichannel sandbars. Natural Hazards, 108(1), 593-605. https://doi.org/10.1007/s11069021-04696-8

Indrapertiwi, C. (2016). Pengetahuan dan Sikap Wisatawan Remaja DIY Tentang Fenomena Rip Current (Studi Kasus di Obyek Wisata Parangtritis Kabupaten Bantul). Jurnal Riset Daerah, 15(3), 25592580.

Kemendagri. (2020). Koordinasi Penyamaan Persepsi Jumlah Pulau di Indonesia Tahun 2020. https://ditjenbinaadwil.kemendagri. go.id/index.php/2020/09/01/koordi nasi-penyamaan-persepsi-jumlahpulau-di-indonesia-tahun-2020/

KKP. (2019). Menko Maritim Luncurkan Data Rujukan Wilayah Kelautan Indonesia.

https://kkp.go.id/brsdm/poltekkara wang/artikel/14863-menkomaritim-luncurkan-data-rujukanwilayah-kelautan-indonesia

Kusmanto, E., \& Setyawan, W. B. (2011). Arus Rip di Teluk Parigi dan Pantai Pangandaran. Ikatan Sarjana Oseanologi Indonesia.

Marfai, M. A., Ahmada, B., Mutaqin, B., \& Windayati, R. (2020). Dive Resort Mapping and Network 
Analysis: Water Resources Management in Pemuteran Coastal Area, Bali - Indonesia. Geographia Technica, 15(2), 106116.

https://doi.org/10.21163/GT_2020. 152.11

Mutaqin, B. W. (2017). Shoreline changes analysis in kuwaru coastal area, yogyakarta, Indonesia: An application of the digital shoreline analysis system (DSAS). International Journal of Sustainable Development and Planning, 12(7). https://doi.org/10.2495/SDP-V12N7-1203-1214

Mutaqin, B. W., Marfai, M. A., Helmi, M., Nurhadi, N., Umarella, M. R., \& Munir, M. (2020). How important risk analysis of plastic pollution in coastal area? Case study in Masohi, Central Maluku. E3S Web of Conferences, 200. https://doi.org/10.1051/e3sconf/20 2020002014

Mutaqin, B. W., Marfai, M. A., Helmi, M., Rindarjono, M. G., Windayati, R., \& Sunarto. (2020). Spatiotemporal mapping of ecotourism activities in Buleleng conservation zone: A methodological review. IOP Conference Series: Earth and Environmental Science, 451(1). https://doi.org/10.1088/1755-

1315/451/1/012095

Mutaqin, B. W., Yuendini, E. P., Aditya, B., Rachmi, I. N., Fathurrizqi, M. I., Damayanti, S. I., Ahadiah, S. N., \& Puspitasari, N. N. A. (2020). Kelimpahan Megabentos Sebagai Indikator Kesehatan Karang Di Perairan Bilik, Taman Nasional Baluran, Indonesia. Jurnal
Enggano, 5(2), 181-194. https://doi.org/https://doi.org/10.31 186/jenggano.5.2.181-194

Ostrowski, R., Schönhofer, J., Stella, M., Grave, A., Babakov, A., \& Chubarenko, B. (2020). South baltic rip currents detected by a field surve. Baltica, 33(1), 11-20. https://doi.org/10.5200/baltica.202 0.1 .2

Republika. (2020). Kunjungan Wisatawan Bantul Tembus 1,7 Juta Orang Tahun Lalu. https://republika.co.id/berita/qmee 1e463/kunjungan-wisatawanbantul-tembus-17-juta-orangtahun-lalu

Retnowati, A. (2013). Rip Currents Signatures Zone Detection on Alos Palsar Image At Parangtritis Beach, Indonesia. Rip Currents Signatures Zone Detection on Alos Palsar Image At Parangtritis Beach, Indonesia, 44(1). https://doi.org/10.22146/indo.j.geo g,2387

Sherker, S., Williamson, A., Hatfield, J., Brander, R., \& Hayen, A. (2010). Beachgoers' beliefs and behaviours in relation to beach flags and rip currents. Accident Analysis \& Prevention, 42(6), 1785-1804.

https://doi.org/10.1016/J.AAP.2010 .04 .020

Susmayadi, I. M., Sunarto, \& Marfai, M. A. (2010). Proses Fisik dan Dinamika Kawasan Pesisir: Rip Current, Abrasi, dan Deflasi. In Sunarto, M. A. Marfai, \& D. Mardiatno (Eds.), Penaksiran Multi-risiko Bencana di Wilayah Kepesisiran Parangtritis (p. 165). PSBA UGM. 
Analisis Spasial Arus Retas sebagai Upaya Pengurangan Risiko Bencana Di Desa Parangtritis Yogyakarta/ Bachtiar W. Mutaqin, Mulyadi Alwi, Natasya Michelle Adalya

Yulianto, A. (2018). Peringkat Destinasi

Dan Strategi Pengembangan Daya Tarik Wisata Pantai Di Kabupaten Bantul Yogyakarta. Jurnal Media Wisata, 16(1), 651-661.

Yunus, H. S. (2011). Metodologi Penelitian Wilayah Kontemporer. Pustaka Pelajar. 